\title{
Capital Structure for Mature Family Companies in the Indonesian Stock Exchange
}

\author{
Pandu Adi Cakranegara \\ Faculty of Business, President University, Indonesia \\ pandu.cakranegara@president.ac.id*
}

\begin{abstract}
Not all family companies choose to float on the Indonesian Stock Exchange. To be a public company, a securities company must comply with various regulations from the supervisory institution that makes its various financial decisions limited by regulations and covenants. Limited financial decision making is a double-edged sword. On the one hand, this can force the company to make more responsible decisions. However, on the other hand, this independence can make the company lag behind other companies that are more flexible in making financial decisions. In order to raise capital, companies can get it to form at least two parties that have an interest in the company's cash flow, namely the lender and the equity investor. This study examines how firms choose the capital structure and its impact on firms. The object of this study is the family businesses that have reached the established phase listed on the Indonesian Stock Exchange. The findings of this study are that mature family businesses have a tendency to maximize cash flow and maintain a dominant position in capital structure and use short-term debt that is less binding or dealing with large banks.
\end{abstract}

Keywords: Capital Structure, Family Business, Financial Flexibility

\section{Introduction}

A family business is a unique company. Its uniqueness, especially in Indonesia, is the family's role that is still high in determining how a company is operated. In order to grow the companies, whether it is a family-owned company or not, one of the alternatives is through the stock exchange (Entimur et al., 2014). Companies can obtain direct public funds that ideally have lower costs, and being a public company is getting supervision from various parties which in return increases trust to the company, respectively. There is also a positive effect of the market to book ratio into equity issue (Yunita, Indiastuti, Ariawati, and Febrian, 2018). However, floating on the exchange also has its challenges. The first challenge is that the company becomes bound by many regulations that, in turn, can reduce the company's flexibility in decision making. They need to publish their financial statements to the public. This financial report can be used by competitors to see the company's strategy (Ghonyan, 2017). Despite that, there are family-owned companies that float on the exchange and even enter the blue-chip list and are considered as established companies. This means that the family business can be said to have successfully utilized the stock exchange to develop its business (Handayani, 2019). After the company enters the established phase, does the initial owner, the family members, do something to the company, such as strengthening control within it? If so, then family members can increase ownership and reduce 
the portion of the debt. This means that the company will have more flexibility in its management with less pressure from lenders (Sharma et al., 2011). This study seeks to answer whether the company will change its capital structure into a certain form or whether there is no significant change that the company makes in its capital structure.

\section{Literature review}

The family business is a special company because it contains family values in running a company. These values can make family companies more competitive or otherwise viewed as less competitive (Chirico et al., 2010). One example is that family companies tend to be conservative in making decisions. Every decision is made after going through a lengthy consideration. Family companies are also sometimes not as quick to adapt to the changes that occur. This conservative nature is not without reason because family companies consider the company to be a legacy of the previous generation that must be protected and a source of income that must be passed on to the next generation. So the sustainability of the company needs to be taken care of carefully. However, family business who welcome conflicts as a part of family firms is more egalitarian in strategic decision making and optimistic toward the future of the firms (Salim, Shariff, and Arshad, 2018). Within the company, there are departments that are generally divided into production, human resources, marketing, finance and strategy. Specifically, incorporate financial decisions have three main decisions, namely funding decisions, investment decisions and dividend decisions (Erhnhart et al., 2016). These three decisions are interrelated. When a company has access to cheap funding, then the company can generate higher value. Similarly, when the company is trusted by the lender, then the company can get long-term assets in large quantities to accelerate the growth of the company.

Funding is an important factor. There are two things that are affected by the funding decision, namely the discount rate and the growth rate. Both of these factors affect the value of the company. The lower the company's discount rate, the higher the company's value. The higher the growth rate of the company, the higher the value of the company (Miao, 2005). A corporate finance manager will try to manage the capital structure to achieve a minimum discount rate to maximize the value of the company. The ideal capital structure can be achieved by using debt assuming there is a tax effect (tax shield) where interest from debt can be recognized as one of the costs of reducing income (Cooper, 2007).

This is a counter-intuitive thing. Conservative companies will tend to avoid debt when debt can lower the discount rate. Excessive use of debt will remove the positive effects of the tax shield by causing financial distress. Therefore, when a company is too aggressive in using debt, it will lower its value and have a higher risk. When a company has debt that is below the industry average and deliberately limits the debt from the amount that minimizes the discount rate, then the company is called under leverage (Minton, 2002). This study examines whether companies use conservative funding policies so as to take under leverage funding policies or companies that minimize discount rates. 


\section{Research Method}

This study is a descriptive-analytical study using quantitative methods. This study aims to examine the decision on the selection of corporate capital structure using historical data derived from corporate financial statements. These historical data are then incorporated into the framework of financial ratios and analyzed using capital structure theory (Penman, 2007). The population of this study is all family companies listed on the Indonesian Stock Exchange in the last five years. Specifically, family companies that have entered the established phase. In the established phase, the company has the characteristics of having not too high growth of not high capital expenditure as well as relatively stable working capital. The consequence of these three is that the company should be able to control better or regulate its cash flow needs, and the consequence is in the selection of its capital structure. This will certainly be different for family-owned companies that are just floating on the exchange who tend to be more aggressive in the use of funds mainly because of the pursuit of potential growth momentum.

The sampling selected in this study is purposive sampling which is a type of sampling where the criteria for determining the sample has been determined before the sampling (Etikan et al., 2016). In this case, some criteria are set for the family business to find a suitable sample for the research needs. The first sampling criterion is the ownership criterion. In this first criterion, the company examined in this study is a family business. The definition of a family business in this study is defined as a company where the founding family still owns a stake in the company above five per cent, and the family members still sit on the board of directors or commissioners. The second sampling criterion is the consolidation criterion. The consequence of the consolidation criteria is that the family business has a parent business in Indonesia and not abroad. Thus the parent company in Indonesia will reflect the consolidated income of all business units. If the parent company is in a foreign company, then Indonesia must be a subsidiary to be consolidated, especially in case of transactions between subsidiaries. Due to the limitations, it is not possible to create a consolidated financial report by the researcher without sufficient transaction data between companies. The third criterion is the industry criterion. The family-owned companies selected as the sample were all family companies except those engaged in the banking and financial services industry. The financial industry is excluded because, in the financial industry, capital regulation is regulated by the government. This capital regulation makes the bank's capital structure must comply with bank regulations and must not be inferior to the minimum regulation. The fourth sampling criterion is the cash flow criterion. The sample taken is a company that has no negative cash flow. Exclusion of companies with negative cash flow is intended because companies with negative cash flow do not have the freedom to determine their capital structure. The fifth sampling criterion is the quality criteria of the financial statements. The family business chosen is the family business that has its financial statements audited with a reasonable opinion without exception. This criterion serves to obtain a credible sample because obtaining reasonable opinion without exception means the company has submitted financial statements in accordance with the standards. The data used were panel data with several variables for some period of time. This study uses a short period of five years to capture a trend-a selection of short-term periods to avoid mean reversions that occur in the long run. 


\section{Result and Discussion}

\subsection{Findings}

Based on the criteria that have been determined in the research method, the family business that has a parent in Singapore is not included as a sample in this study. This means that Lippo Group and Sinar Mas Group are not included because these two companies are a parent and registered as public companies in Singapore. Meanwhile, family companies such as Bakrie, which owns the parent company Bakrie and Brother, cannot be included because the parent company still has negative profits. From the sample, there are six parent companies from the family business conglomerate listed on the Indonesian Stock Exchange. The six companies are Alfa, Ciputra, Astra, Indofood, Gudang Garam and Blue Bird. In the cigarette industry, there are several companies that can be added, such as Sampoerna and Bentoel. However, if these two companies are included, then the cigarette company shares will dominate the shares in the sample. In addition, there are new family companies such as Garuda Food that are not included because they still do not have data for four years. This is because this company has just floated on the exchange even though it has been operating for a long time. Companies in financial services owned by family companies such as Bank BCA, Bank Pan Indonesia and Bank Mayora are not included due to regulatory reasons. The capital structure of the company is regulated by Bank Indonesia, and thus the bank is not free to determine its capital structure.

\subsection{Ratio Analysis and Capital Structure}

To compare the capital structure of the company, the ratio of Debt to Asset Ratio, Debt to Equity Ratio and Debt to EBITDA Ratio is used. The DA ratio is useful for measuring the proportion of debt compared to total assets. The DE ratio is useful for measuring the proportion of debt compared to total equity. In contrast, the D / EBITDA ratio is useful for measuring the proportion of debt compared to the company's net cash flow (EBITDA).

Based on this analysis, the company with the largest proportion of debt is owned by Alpha. This may be due to the influence of the retail industry on companies storing large supplies from third parties. This will give rise to high short-term obligations, thus increasing short-term debt. If adjustments are made by making adjustments to the industry, then the debt ratio will be at the level of 35 to 40 per cent.

From table 1, it can be seen that Blue Bird has the lowest debt. This can be related to the industry. However, this needs to be looked at further. The reason is that competitors from Blue Bird, Express, use a much higher level of debt. Express, which is also an open company, even fails to pay due to the influx of online taxis, which reduces the company's revenue.

From table 1, it can be seen that Ciputra has a slightly larger debt than its equity. Keep in mind that Ciputra is a real estate company. In the property industry, longterm financing is a crucial factor in the development of a project. In the valuation of property, it is necessary to keep in mind the inventory of land or land bank owned by the company. If this land bank is revalued to its current value, then its value will increase. An increase in the value of bank land on assets will increase the equity portion of the company, thus reducing the debt ratio. With this note, Ciputra 
actually has a smaller debt ratio than equity. Thus, judging from the capital structure, the most common family firms on the stock exchange tend to have a more conservative capital structure policy, which is to use higher equity than debt.

Table 1. Debt to Asset

\begin{tabular}{|l|l|l|l|l|}
\hline \multicolumn{1}{|c|}{ D/A } & 2019 & 2018 & 2017 & 2016 \\
\hline ALFA & 0,72 & 0,74 & 0,77 & 0,74 \\
CIPUTRA & 0,51 & 0,51 & 0,51 & 0,51 \\
ASTRA & 0,47 & 0,49 & 0,47 & 0,47 \\
INDOFOOD & 0,44 & 0,48 & 0,47 & 0,47 \\
GUDANG GARAM & 0,35 & 0,35 & 0,37 & 0,37 \\
BLUEBIRD & 0,27 & 0,24 & 0,24 & 0,36 \\
\hline
\end{tabular}

Source: Author calculations, 2020

Table 2. Debt to Equity

\begin{tabular}{|l|c|c|c|c|}
\hline \multicolumn{1}{|c|}{ D/E } & 2019 & 2018 & 2017 & 2016 \\
\hline ALFA & 2,58 & 2,78 & 3,29 & 2,79 \\
CIPUTRA & 1,04 & 1,06 & 1,05 & 1,03 \\
ASTRA & 0,88 & 0,98 & 0,89 & 0,87 \\
INDOFOOD & 0,77 & 0,93 & 0,88 & 0,87 \\
GUDANG GARAM & 0,54 & 0,53 & 0,58 & 0,59 \\
BLUEBIRD & 0,37 & 0,32 & 0,32 & 0,57 \\
\hline
\end{tabular}

Source: Author calculations, 2020

Table 3. Debt/EBITDA

\begin{tabular}{|l|c|c|c|c|}
\hline \multicolumn{1}{|c|}{ D/EBITDA } & 2019 & 2018 & 2017 & 2016 \\
\hline ALFA & $72 \%$ & $74 \%$ & $77 \%$ & $74 \%$ \\
& 5 & 4 & 3 & 3 \\
\hline CIPUTRA & $51 \%$ & $51 \%$ & $51 \%$ & $51 \%$ \\
& 3 & 2 & 2 & 2 \\
\hline ASTRA & $47 \%$ & $49 \%$ & $47 \%$ & $47 \%$ \\
& 38 & 38 & 31 & 24 \\
\hline INDOFOOD & $44 \%$ & $48 \%$ & $47 \%$ & $47 \%$ \\
& 11 & 10 & 11 & 9 \\
\hline GUDANG GARAM & $35 \%$ & $35 \%$ & $37 \%$ & $37 \%$ \\
& 16 & 12 & 12 & 11 \\
\hline BLUE BIRD & $27 \%$ & $24 \%$ & $24 \%$ & $36 \%$ \\
& 0,5 & 0,7 & 0,7 & 0,9 \\
\hline
\end{tabular}

Source: Author calculations, 2020 
The second thing seen is the use of cash flow to meet the funding needs of the company. Based on the theory of Pecking Order capital structure, the company will prioritize using internal cash flow first to meet its operational needs. After that, if the internal cash flow is not enough, then the company will increase funding by using loans. The last option of a company is to sell equity and share ownership (Serrosquerro et al., 2015).

To know the tendency of companies to use cash flow, we can see the comparison of debt compared to net cash flow which in this case is represented by EBITDA, namely Earnings Before Interest Tax and Debt. From table 3, it can be seen that the use of EBITDA rises slightly higher but tends to be stable. Salt warehouses such as debt usage decreased from 37\% EBITDA to 35\% EBITDA but remained in the range of 30 per cent. Astra has a debt that rises in one year but tends to be stable at $47 \%$.

Another indicator that can be used to perform additional analysis and crosschecking is to use the DE ratio. This ratio is useful for looking at the comparison between debt and equity. From this comparison, it can be seen that the trend of debt usage decreased over the last four years of the whole sample.

\section{Conclusion and Implications}

From the results of the ratio analysis, it is seen that all the family companies selected based on purposive sampling have the same pattern after the industrial adjustment. All family companies have a smaller portion of debt than equity. From year to year, the portion of debt compared to the portion of cash flows tends to decrease even though the amount of the decrease is relatively small. From these two, it can be concluded that the family business has a conservative capital structure policy. Another conclusion that can be drawn is that family companies have a stable capital structure policy. Both of these conclusions can be drawn due to the consistency of the output of the ratio analysis value.

A ratio analysis approach is an approach that simplifies. But this approach has the advantage of showing the pattern on a set of data in this case to the family business. To do a more in-depth analysis of the future can be done by using several other ratios for each industry. In addition, other frameworks can be used to view corporate capital structure policies.

\section{References}

Cooper, I. A., and Nyborg, K. G. (2007). Valuing the debt tax shield. NHH Dept. of Finance and Management Science Discussion Paper, (2007/15).

Chirico, F., and Nordqvist, M. (2010). Dynamic capabilities and trans-generational value creation in family firms: The role of organizational culture. International Small Business Journal, 28(5), 487-504.

Ehrhardt, M. C., and Brigham, E. F. (2016). Corporate finance: A focused approach. Cengage learning.

Ertimur, Y., Sletten, E., and Sunder, J. (2014). Large shareholders and disclosure strategies: Evidence from IPO lockup expirations. Journal of Accounting and Economics, 58(1), 79-95. 
Etikan, I., Musa, S. A., and Alkassim, R. S. (2016). Comparison of convenience sampling and purposive sampling. American Journal of theoretical and applied statistics, 5(1), 1-4.

Ghonyan, L. (2017). Advantages and Disadvantages of Going Public and Becoming a Listed Company. Available at SSRN 2995271.

Handayani, M., Farlian, T., and Ardian, A. (2019). Firm Size, Market Risk, and Stock Return: Evidence from Indonesian Blue Chip Companies. Jurnal Dinamika Akuntansi dan Bisnis, 6(2), 171-182.

Miao, J. (2005). Optimal capital structure and industry dynamics. The Journal of finance, 60(6), 2621-2659.

Minton, B. A., and Wruck, K. H. (2002). Financial conservatism: Evidence on capital structure from low leverage firms.

Penman, S. H., and Penman, S. H. (2007). Financial statement analysis and security valuation (Vol. 3). New York: McGraw-Hill.

Salim, L., Shariff, M. N., and Arshad, D. A. (2018). Predecessors' Attitude Toward Conflict Predictor of Family Business Sustainability. International Journal of Family Business Practices, Vol. 1, Iss. 1, pp. 1-13.

Serrasqueiro, Z., and Caetano, A. (2015). Trade-Off Theory versus Pecking Order Theory: capital structure decisions in a peripheral region of Portugal. Journal of Business Economics and Management, 16(2), 445-466.

Sharma, P., and Salvato, C. (2011). Commentary: Exploiting and exploring new opportunities over life cycle stages of family firms. Entrepreneurship Theory and Practice, 35(6), 1199-1205.

Yunita, I., Indiastuti, R., Ariawati, R. R., and Febrian , E. (2018). Moderating Impact of Ownership Structure on Relationship of Equity Market Timing with Capital Structure on Companies Listed on Indonesia Stock Exchange. International Journal of Family Business Practices, Vol. 1, Iss. 2, pp. 3952. 
This page is intentionally left blank 